\title{
VERTALING VAN SARGA XXII EN XXIII VAN HET OUDJAVAANSCHE RĀMĀYANA.
}

\author{
DOOR
}

\author{
Dr. H. H. JUYNBOLL.
}

\section{Sarga XXII $\left.{ }^{1}\right)$.}

Daarop toen Daçamuka ingelicht werd omtrent den dood van den patil, werd zijn gemoed hoe langer hoe bevreesder en beefde hij zonder ophouden. Zeer verschrikt stond hij bij de hoofdpoort der burcht en zijn gelaat was bleek. Snel sprak hij (1):

„O gij rākşasa's! Wekt toch mijn jongeren broeder en maakt hem wakker! Kumbhakarṇna handelt verkeerd, dat hij zoo vast slaapt. Hij verlustigt zich voortdurend en denkt niet na, als een buffel. Omhuld door duisternis is hij onbezorgd en zeer verblind" (2).

Zoo sprak Daçamuka. Zij stonden allen op. Zij kwamen en sloegen op trommen en anderen bliezen op bazuinen en tritonhoorns. Anderen sloegen op bekkens, komvormige muziekinstrumenten, rěgang's ${ }^{2}$ ) en feestmuziektrommen, zacht en luidklinkend. Die werden door hen geslagen, bulderend, tegelijk, gezamenlijk luidklinkend (3).

Het samentreffen van het geluid der trommen was geducht als de donder. Het handgeklapgeluid van de bekkens was als de donderslag. Evenwel werd er niets van gehoord door hem, dien zij trachtten te wekken. Integendeel werden de handen van hen, die de bekkens met groot geraas sloegen, vermoeid (4).

$\mathrm{Zij}$, die hem trachtten te wekken, werden ongerust; hij, dien zij wilden wekken, snurkte. Allen vertoonden hunne listen: sommigen beten hem. Er waren er, die hem staken met hunne harde nagels, doch die braken af. Er waren er, die hem met een mes staken, doch dit boog krom en (dreigde) tenslotte uiteen te vallen (5).

1) Sarga XXI is vertaald in deel 90, p. 301-328 dezer Bijdragen. De eerste verzen van dezen sarga zijn reeds door mij vertaald in 6 e volgr. deel VI.

2) Over de beteekenis van dit en andere hier vermelde muziekinstrumenten vergelijke men het register in $\mathrm{Mr}$. J. Kunst (met medewerking van Dr. R. Goris), Hindoe-Javaansche muziek-instrumenten, speciaal die van Oost-Java, 1927. 
Er waren helden, die snelloopende paarden bereden. Zij trachtten hem te wekken door allen op zijn lichaam te trappen, niet zacht. Zelfs lieten zij 500 olifanten op hem trappen. Hij meende, dat men hem liefkoosde bij het trappen en het was hem aangenaam (6).

Er waren wagens, zoo groot als bergen, die men op hem liet trappen. Het was alsof hunne wielen hem voortdurend zachtjes streelden. Het geluid van de bulderende trommen klonk hem als zacht gekweel. Hoe langer hoe luider was zijn gesnurk, donderend en daverend (7).

De middelen, die in allerlei soorten werden aangewend, waren ten einde. Die waren niet de oorzaak, dat hij ontwaakte, doch dit was toevallig. Het terugkomen tot zijn bewustzijn, dat was de oorzaak, dat hij ontwaakte. Vervolgens streek hij over zijne oogen en werd wakker. Snel sprak hij (8):

„Wat is de reden ervan, waarom ik gewekt word?" Daarop antwoordden zij allen verheugd en eerbiedig: „Dit is het bevel van den vorst, dat wij gelast worden op te volgen. Bij de komst van den vijand is de oude patih gesneuveld (9)".

Dit waren de woorden van de troepen, die hem gelastten, binnen te treden. Daarop waschte hij zijn gelaat, versierde zich, verkleedde zich, tooide zich met bloemen en blankette zich. Vervolgens werd hem als ontbijt rijst gebracht bij het ontwaken. Duizende, tienduizende, honderdduizende rijststoommandjes at hij ineens geheel op (10).

Gekookte spijzen, het vleesch van leeuwen en olifanten was gereed gezet en opgestapeld. Tientallen manden vol at hij ineens in een oogenblik. Hoevele kruiken met dranken er ook waren, hij dronk ze alle uit in een oogenblik, want hij was vreeselijk dorstig (11).

$\mathrm{Na}$ ontbeten te hebben, ging hij vervolgens naar binnen en ging hij in het paleis zitten. Bij zijn binnentreden vond hij zijn ouderen broeder bekommerd en nadenkend. Zijn gelaąt was bleek en hij zuchtte en had hartkloppingen en hij was bang, als teeken van zijn groote vrees. Hij sprak zacht en langzaam (12):

,.Mijn jongere broeder! Groot is uwe verblinding, dat gij zoo vast slaapt. Weet gij dan niet, dat uw vijand gekomen is met de apen, zijne troepen, in grooten getale? (13).

„Velen zijn door hem gedood op het slagveld, Mitraghna en Kumbha zijn de eersten van hen en verder Dhūmrākṣa, Wirūpākṣa, Akampana en Praghasa (14).

„Dit zijn de eersten van de gesneuvelde helden. $\mathrm{Zij}$ waren vroeger 
helden, uitmuntend in kracht en ook de oude patih is reeds gesneuveld, machteloos (15).

„Slechts gij zult mijn beschermer zijn, jongere broeder! en gij zult al uwe vijanden verdelgen. Maak den lagen Rāma in eens af en Lakșmana en Sugrīwa mogen (door u) stuk gewreven worden! (16).

„Laat ik bij deze gelegenheid uwe liefde jegens uw ouderen broeder zien! Als uwe vijanden verdelgd en weggevaagd zijn, zal uwe dapperheid blijken op het slagveld en zal uw roem zich verspreiden in de drie werelden (17).

„Blijkbaar zal Daçaratha's zoon onderdoen, want het is van ouds uw aard, te zegevieren. Zelfs de machtige goden zijn $u$ onderdanig en de drie werelden hebben ontzag en eerbied voor $u$ " (18).

Nadat Rāwaṇa gesproken had, antwoordde zijn jongere broeder snel: „Ik weet niet, wat ik zal zeggen tot $\mathrm{u}$. Ik ben verlegen, wat ik zal doen (19).

„Vele juiste woorden hebt gij vroeger gesproken. Zeer moeilijk was het, die te gehoorzamen. De lessen aan u waren verspild, want onbesuisdheid en overmoed beheerschten (u) (20).

,En het doel van mijne woorden was heilzaam, het welzijn van al uwe verwanten. Velen toch van de helden zijn gesneuveld. Het is verkeerd, $u$ daarover te kwellen (21).

,.V roeger toen gij aangespoord werdt tot het goede, toen gij beraadslaagdet, waart gij verblind. Allen, die $\mathrm{u}$ aanmaanden, werden beknord. Zij, die aanspoorden tot beleid, werden bespot (22).

„In plaats van hunne woorden ter harte te nemen, verwierpt gij alle woorden van hen, die $\mathrm{u}$ waarschuwden. Uw hoogmoed was zoo groot als een potvisch, die zich bevond in uw oor (23).

„Uw jongere broeder vermaande u vroeger; op alle gevaren werd u gewezen, doch gij gaaft geen gehoor aan die woorden. Ook uw grootvader trachtte $u$ te vermanen (24).

„Voorbeelden werden $\mathrm{u}$ voor oogen gehouden, doch zij werden toch niet door $\mathrm{u}$ ter harte genomen. De nectar der woorden stroomde tevergeefs; in uw hart verscholen zij zich (25).

„De oude is niet in staat, zich om te wenden en de brave zal niet geëerbiedigd worden. Hij zal de leerboeken niet kennen; dat is ongerijmd en niet te begrijpen (26).

„Hij is immers het toppunt der waarheid, de wenschen der wereld worden geprezen. Niet anders dan de grootvader jegens de moeder, verdient hij volkomen gehoorzaamd te worden (27). 
„Gij gehoorzaamt niet uwe ouders en hebt geen aanhankelijkheid voor hen, die geëerbiedigd behooren te worden. Alle woorden der dwazen worden (door $\mathrm{u}$ ) gevolgd, doch het smaken van de vrucht hiervan is nu gekomen (28).

„Onwetend verzinkt (gij) in de zee, dat is de onbesuisdheid, breed en diep. Uwe voortdurende begeerte is als de golven; uw groote hartstocht is te vergelijken met de groote golven (29).

„Uwe vreugde is hevig als de branding; uw zelfzuchtige inborst is als de klippen. Uw toorn is als de wind met stormvlagen; uwe verblinding is als een donkere groote wolk (30).

,Als een haai in den strijd zijn uwe ruwe woorden; uw nijd is als een verdelgende visch. Uw afgunst is als een wreede dolfijn (makara) met opengesperden bek; uwe minachting is als een vergiftige slang (31).

„Uwe heftigheid is als een gespleten vaartuig; uwe kennis is als de verrotte en vergane kiel daarvan. Uwe aanhankelijkheid is als de gebroken en geknakte mast daarvan; uw inborst is als het kapotte en gescheurde zeil daarvan (32).

„Uw trouw is als het, door den storm meegesleepte roer daarvan; uwe verdiensten zijn als de verdwenen lading daarvan. Uwe geliefde is gescheiden, deerniswaardig, daar in het hellevuur gevallen (33).

„Al uwe makkers zijn gewelddadig, zij verwoesten de wereld. Er is niets, waarin gij hen onderricht; blijkbaar zult gij naar de hel gevoerd worden (34).

„Al uwe wenschen worden door $\mathrm{u}$ gevolgd; uwe vaandels brengen de wereld in opschudding. Voorteekens bestrijdt gij voortdurend, gemeen en de schuld gevende aan onschuldigen (35).

„Geleerden worden bespot door de slechten; goud is hun doel, waarin zij slagen. Zij zijn er afkeerig van, goede lieden te zien, maar houden van hen, die zich slecht gedragen (36).

„De goeden buigen zich nederig, waarom zij hen hoe langer hoe meer minachten. Als zij echter weerstaan en bestreden worden, raken zij in verlegenheid en worden hoe langer hoe woester (37).

„Hoewel gij het slechte inziet, hebt gij er lust in en verhindert gij het niet. Uw inborst is nu eenmaal zoo en nu zal de vrucht hiervan komen (38).

„Wees er niet bekommerd over, dat gij zult sterven, want gij zijt er de ware oorzaak van. Door de verblindheid van uw gemoed is het, dat $\mathrm{u}$ dit overkomt; de zes verkeerde hartstochten zijn in opschudding in uw hart (39). 
,Zoolang gij bezeten zijt door verblinding en trots, zouden zelfs yakșa's, asura's en goden, ook zij zouden zeker omkomen door dien trots, als die hevig brandt" (40).

Zoo waren de woorden van zijn jongeren broeder Kumbhakarnnna, hem verwijtende. Rāwana sprak vertoornd: „Ha! Foei! Schelm, die zich gerechtigd acht, alles wat in zijn gemoed is uit te spreken zonder zich te bedwingen. Gij zoekt, gij vindt schoons zonder dat gij verhinderd wordt en zonder onderricht te worden in beleid. Als gij echter durft, laat ik $\mathrm{u}$ dan woedend aanvallen of laat ik door $\mathrm{u}$ vertoornde aangevallen worden (41).

„Wat baat het, voortdurend te vermanen? Ik word er door gestoord zonder doel. Wat zou het nut zijn voor een held, om voortdurend langdradig, zwaar op de hand en welbespraakt te spreken? Slechts kracht wordt vertoond door een held, geen massa van woorden. Gij echter vermaant met ach! en o! Inderdaad zijt gij iemand, die diep slaapt en geeuwt" (42).

Zoo waren de woorden van zijn ouderen broeder. De jongere broeder stond standvastig op en greep naar zijne wapens. Hij schreeuwde gedrukt en hief een leeuwengebrul aan, waardoor het luchtruim geheel vervuld werd en vol en bedekt. $Z$ ij stoven verschrikt uiteen en alle goden raakten in opschudding en verwarring. God Kāla was uitgeput en bevreesd, kroop ineen, dook weg en was verschrikt (43).

De geheele wereld wankelde, beducht op het oogenblik, dat Kumbhakarṇna zich op weg begaf. De aarde schudde, beefde en trilde en zakte ineen, alsof zij verdelgd zou worden. De Himawān beefde en de Sumeru trilde en voortdurend daverde de oceaan. De wereld schrikte en was ontsteld en de nāga's waren op hunne hoede, beducht voor de toekomst (44).

Nadat hij een verguld harnas had aangetrokken, welks glans rood straalde, werd het helder licht, als een brandende berg, zoo geducht was hij, om te zien. De oogen van allen, die hem zagen, werden verblind en zij sloten hunnen oogen en sloegen ze neder. De Zonnegod deed onder in glans, verbleekte en was beschaamd en hield op te stralen (45).

Wat geduchtheid betreft was hij als god İçwara, zich vertoonende in de gedaante van Mahābhairawa. Wat grootte en hoogte betreft was hij als de Meru, niet anders. De zon bij den wereldondergang, hevig heet, daarop geleken zijne oogen. Als de Doodsgod was zijn gelaat, zeer scherp, wreed, met puntige slagtanden (46). 
Zijne neusgaten waren breed en verbazend donker en diep als een grot en zijne ademhaling suisde als een stormwind of een stormvlaag. De boomen braken en braken af, werden vernield en vielen, omvergesmeten en hunne takken werden afgerukt en gebroken. Alle leeuwen, die in het kreupelhout waren, vlogen weg en de dieren zochten hunne toevlucht in holen (47).

Als teekens ervan, dat hij zou sneuvelen op het slagveld, vertoonden zich voorteekens, die den dood veroorzaken. Roode wolken boven in het uitspansel, een onophoudelijke regen van bloed, vleesch en ingewanden. Kraaien krasten verschrikkelijk, rondvliegende en vele meteoren vielen neder. Voortdurend trilde zijn oog en zijn linkerarm beefde (48).

Doch hij was niet verbaasd en onverstoord, telkens als hij die voorteekens zag, die niets goeds voorspelden. Hoe langer hoe vermeteler trad hij vooruit, de apen, die hem overstelpten, tegemoet gaande. Alle apen omslingerden hem en beklommen hem, zoodat zijn lichaam door hen bedekt werd, evenals een berg, waartegen de wolken zich verzamelen en hem snel bedekken (49).

Toen werd Kumbhakarṇna overstelpt door de apen, die opgewonden vielen op den berg. $\mathrm{Zij}$ gooiden, sloegen, stieten, wierpen werpschijven op steenen en staal, trachtende met hunne vuisten en handen op zijn neus te slaan. $\mathrm{Zij}$ ranselden en sloegen, vielen aan en schopten, stieten met de knieën, duwden en trokken. Zij zochten allerlei hulpmiddelen, beten en staken met hunne nagelspitsen, zijne oogen uitstekende.

Evenwel deerden zij hem niet, doch daar braken de steenen en werden de bergen verbrijzeld en de stokken vergruizeld. Onmiddellijk daarop viel Kumbhakarṇna op zijn beurt aan; weergaloos vele apen at hij op. Zijne beide handen smakten beurtelings neer op hunne dijen en knieën en zij werden gebroken, opengescheurd en verbrijzeld. Hunne ingewanden werden uitgerukt; de nek, der apen werd gebroken en het bloed van anderen spatte er uit en werd door hem opgeslorpt.

Er waren er, die geknepen werden, onbewegelijk, gedrukt, geknakt, met een knots geslagen. Velen werden gespietst, achteroverliggend, hun tong uitstekende en de tong van anderen werd afgehouwen, geslagen en plat gedrukt. Anderen werden vertrapt en er waren apen, wier staart gegrepen werd; zij spartelden en trokken, krachteloos, trachtende te spartelen, geklemd; de huid van hun staart werd geschaafd, afgestroopt en ontveld. 
Hoe langer hoe erger werd de woestheid van Kumbhakarṇna; hij was vertoornd, onverzadigd van het verslinden der apen. Bij ieder, die vooruittrad, nam zijn honger toe; zijn buik werd niet gevuld door de apen, hoevele honderdduizende en tienduizende er ook waren) zij werden in een oogenblik verminderd. Talrijk was hunne vermindering, doch zijn honger verminderde niet; als het vuur van den Doodsgod, zoo geducht was het vuur in zijn buik; al wie er binnenging werd zonder overschot tot asch verteerd (50).

Evenals god Kāla alle wezens verslindt tijdens het einde van een wereldtijdperk, dansende op een kerkhof, verdelgend, bemorst met bloed en hersenen, daarmede was hij te vergelijken, belaagd wordende; alsof hij zich met een brahmanensnoer omwonden had, waren de ingewanden. Dat is de versiering van Mahākāla, ten tijde dat hij de wereld verzamelt en haar vernielt, met hem was Kumbhaharṇna te vergelijken, met bloed besmeerd en alle apen verslindende.

Verschrikkelijk als de Berggod was hij om te zien; geducht was zijn muil door het bloed van alle apen, dat rood was als een mineraal, spattende en de berggrotten vullende. De apen waren niet in staat, hem te zien; vooruittredende werd hun gemoed verduisterd door vrees en vervaard en verschrikt stoven zij weg, de aarde niet ziende; meenende dat de aarde verduisterd was, vluchtten zij, terwijl zij trachtten, zich te verschuilen in het kreupelhout.

Er waren er, die hunne toevlucht zochten op de toppen der bergen, grotten opzoekende tot bescherming van hun leven, weshalve zij trachtten zich te verbergen in spelonken en afgronden. Anderen klommen in groote boomen, katoenboomen, broodboomen, mangga's, $k \breve{e} p u h ' s$ en ficussen, daarin klommen zij. De boomen waarop zij zaten, schudden, trillende, alsof zij afkeerig ervan waren, dat zij tot bescherming strekten van de apen, omdat zij laag en gemeen waren, vluchtende in den strijd,

schuddende en sidderende; hunne zitplaats was niet vast. De boomen, waarop zij gevlucht waren, trilden. $\mathrm{Zij}$ sprongen, zittende, zich klemmende aan de takken. Anderen waren bang, overal waarheen zij gingen, sidderden zij en waren zij bevreesd. Er waren er, die klommen op arèn-palmen, zich veilig achtende, hun lichaam in arèn-vezels wikkelende, (doch) doorboord werden door die vezels, krachteloos. Ach! zij vluchtten en daalden naar beneden (51).

De apen ritselden en werden ontredderd; daar beneden (klonk) hun geluid, terwijl zij hunne toevlucht zochten op den Suwela; langen D1. 92. 
tijd waren zij vermengd, wegvliedende, verward, bedroefd, verdrietig: niet langer beschaamd, kruipende, gebogen, vertrapt door hunne makkers; tengevolge van het gedrang op de helling, daalden zij snel af naar de zee, hoe langer hoe meer in opschudding vluchtten zij naar den dam. Gezamenlijk nagezet waren zij onafgebroken opgestapeld, dringende, gestooten en gebotst wordende. Anderen daar aan den kant van den dam verloren hunne bezinning en vielen in zee, deerniswaardig zwemmende. De toeschouwers konden nauwelijks hunne tranen bedwingen, ziende dat zij gestooten werden en neergesmeten. Het was duidelijk, dat zij weggeslingerd werden en gebeukt door den stroom en verpletterd; de randen van hunne billen werden gebogen en geknakt.

Het was alsof de apen geen weerstand meer zouden bieden; zij zochten hunne toevlucht op den Mahendra, trachtende zich rustig te vestigen in grotten, niet denkende aan de tijgers, want zij waren verblind door vrees. Anderen waren er, die zich verborgen in bamboe doeri. In opschudding zochten zij den weg, maar vonden dien niet, gewond als zij werden door de dorens van de bamboe docri. Ach! Wat verlangden zij te leven, hoewel het smart veroorzaakt aan lieden, dien er te zeer naar verlangen. Dat ziende, was Anggada buitengewoon beschaamd, ziende hoe de apen overwonnen werden als varkens, naar zijne meening. Zijn gemoed was standvastig, doch hij was alleen, verlaten, uitstekend, afwerend, zich verzettende tegen de groote schande, weshalve hij hen vermaande: „Waardeert de woorden der heilige schriften en houdt $u$ aan de kennis der ware helden in den strijd, gij apen, allen! (52).

„Er is echter een offer op het slagveld, dat is de wetenschap der helden, wanneer zij krachtig zijn, der helden, die standvastig zijn, die stand houden in den strijd, strevende naar het toppunt van goedheid; zij beschouwen zich niet als geheel alleen, als zij onbedekt staan en alleen gelaten worden. „Niet snel een ander mensch is het doel van den geest, die in een oogenblik verdwijnt". Zoo denkt hij, woedend strijdende op het slagveld. Zoo moet ook gij (denken), apen!

„Wat is het nut en het doel van dit leven, als men niet prijst en niet geprezen wordt op het slagveld. Dat is te beschouwen als een offeroven van de helden. Zoo is de vijand te vergelijken met het vuur en zoo zijn de blinkende wapens te beschouwen als de vlam. Zoo is onze heldhaftigheid te beschouwen als de groote en kleine offerlepel ervan en als het offer het leven van het lichaam, dat de 
vijf benoodigdheden bij het offer mogen strekken, dat is onze kennis van de heerlijke vijf wapens ${ }^{1}$ ).

„Vooral als de vijanden zonder overschot gedood worden door ons op het slagveld, dan is ons offer blijkbaar. Het is werkelijk jammer, dat gij inspanning verricht; slechts de gedachten van hem, die helder voortdurend denkt aan god Mahāwīra Bhadreçwara, het gebed stil herhalend op het slagveld, de vrouwen van de offerplaats zijn ons brandhout, de lijken der vijanden een volmaakt en volkomen offer van bloed en hersenen.

„Wat ontbreekt er aaan lofprijzingen in den strijd, want volledig toegerust met yoga is uw gebrom, uw gehinnik en uw geschreeuw, dat is uwe lofprijzing van het luide leeuwengebrul op het slagveld, dat den hemel vreugde schenkt, waardoor uw partij genot smaakt door uw macht, tengevolge van uwe heldhaftigheid, standvastigheid en heldenmoed en ook roem, waarnaar gij streeft te verwerven door groote helden, wordt gij op aarde geprezen" (53).

Zoo waren de woorden van Anggada, die hen gelastte om den strijd weder te hervatten. Het gemoed der apen was verheugd en zij stonden op, alsof zij aangevuurd werden. $\mathrm{Zij}$ waren niet bevreesd om te sterven, doch woedend strijdende, traden zij weder naar voren, daverend, in groote menigte, evenals de zee, wanner de vloed opkomt (54).

Zij bromden, hinnikten en schreeuwden luid, als de donder, zoo vreeselijk was hun geluid, toen zij juichten. Hun gemoed was verheugd en zij traden allen vooruit, kletterend, toen zij den zin van de heilige geschriften ${ }^{2}$ ) hoorden. Zij verlangden te sneuvelen. „Het kan niet anders", zoo spraken zij allen. Hunne lichaamsharen waren rossig, gekruld en glanzend en het hoofdbaar van alle apen wapperde (55).

Alle helden wachtten en zij stonden op in grooten getale en de apen makkten zich gereed, ten getale van honderd, vele honderdduizenden en tienduizenden rangschikten zich als de zee. Het Noorden en het Oosten waren vol en ook het Westen en het Zuiden waren gevuld door de wachtende apen. Kortom, zij waren allen gewapend met stokken, die zij hanteerden, van uitgerukte manggaboomen (56).

Nadat zij boomen gegrepen hadden, waren hunne wapens zeer

1) De beide laatste strophen van dit vers zijn vertaald door Dr. Poerbatjaraka in T. I. T. L. Vk. LXXII, p. 171.

2) In plaats van çāstra hetu, zooals in den tekst staat, lees ik: çāstrahetu. 
gruwelijk, als bergen. Alle helden traden naar voren, hoe langer hoe daverender doordat hunne makkers in opschudding geraakten. De boomen trilden en er suisde een sterke luchtstroom, (veroorzaakt) door den rākșasa Kumbhakarṇna. De adem van zijn neus was verschrikkelijk en geducht en voortdurend krachtig (57).

Nìla, Rṣabha, Gandhamādana, Gawa, Gawaya, Tāra, Krandana, Indrajānù en Çatabali, Winata en Dhūmra, Gawākṣa, Bhīmamuka, Mainda, Çarabha, Wṛ̣abha, Sampāti en Darīmuka waren de eersten van het apenleger, die vooruittraden (58).

Zij waren allen volledig toegerust en zwaaiden bergen omhoog, anderen droegen groote steenen. Daarop volgden de gewone apen, aandringende, stukken hout grijpende, die knapten. Zij traden allen vooruit, overstelpend, allen onstuimig slaande. $Z_{\mathrm{ij}}$ stieten en wierpen met bergen; de steenen knetterden en vonkten (59).

Niet gedeerd werd hij, die gestooten werd, van alle kanten aangevallen, hier en daar omsingeld. De bergen en vlakke steenen werden gespleten en alles wat tot hem kwam werd verbrijzeld en werd tot asch; de stof was verschrikelijk en dwarrelde, zoodat het luchtruim verduisterd werd. I)e aarde trilde en dreunde en er viel een aschregen, toen hij overstelpt werd (60).

Geducht was de wind, de storm woedde en het leger schreeuwde verward dooreen. De plaats van het slagveld was onzichtbaar en er heerschte overal eene tastbare duisternis. Kumbhakarṇna was vertoornd en woest en kwaadaardig als een dolle olifant. Zij werden vertrapt, platgedrukt en vertreden. $\mathrm{Zij}$ schreeuwden, bij zeven en bij vier tegelijk (61).

Andere apen werden verslonden of gedrukt en er waren er, die geklemd werden en hun kop werd verpletterd en verbrijzeld en vermorzeld en hunne oogen puilden uit, plat gedrukt. Anderen werden in de lucht geslingerd en stierven, getroffen door den wind uit zijne neusgaten. Velen werden opgeslurpt, 'in eens afgemaakt, getroffen door het gedroogde snot, alsof het een rotssteen was (62).

De apen werden verdelgd en gekauwd; er waren er, die telkens werden gebeten en hapten en staken, doch zij deerden hem niet en onophoudelijk stierven zij; hun huid werd afgeschaafd en liet los. Hun bloed stroomde en vloeide; anderen werden bleek en er waren er, die bedekt werden door groote steenen en gestooten door de teenen van zijne voeten (63).

De apen waren bevreesd en niet in staat om den strijd te hervatten, verschrikt en ontzet, ziende dat ieder van hunne makkers, die vooruit- 
trad, stierf en er geen was, die levend terugkeerde. Hij was naar hunne meening geen rākșasa, doch de vernielende Kāla ${ }^{1}$ ) in levenden lijve. Daarom troken zij weder terug, weggedrongen en verslagen en was er niemand, die tegenstand bood (64).

Toen het apenlegẹr vluchtte en aanhoudend verdelgd werd, toen sprak Wibhīsana tot den zegevierenden telg van Raghu: „Laat de vorst op zijne hoede zijn en niet lijdelijk toezien, want deze is werkelijk gevaarlijk. Blijkbaar zullen de apen door hem verdelgd worden, wanneer gij hierbij lijdelijk toeziet (65).

„Deze rākșasa Kumbhakarṇna is vermaard als overwinnaar van de drie werelden. God Indra is verslagen en ook Baruna, Waiçrawana en Yama. Zijn kracht is geducht als een onweersstorm bij den wereldondergang. Alles wat door hem omvergerukt wordt, wordt vernield. Daarom moet hij afgemaakt worden" (66).

Toen vorst Rāma zoo toegesproken werd, beval hij den apenvorst vooruit te treden. Sugrīwa begeerde roem te verwerven in den strijd. Toen hij nu bevolen werd, werd hij hoe langer hoe verheugder (67).

Hij rukte een boom uit, zoo groot mogelijk, zoodat zijne afmeting honderd el bedroeg; geweldig was zijne breedte en zijne lengte; als diamant was zijne hardheid, buitengewoon hard (68).

Een slingerplant, de Gnetum Gnemon, van een vadem omwikkelde hem en omkronkelde hem, strekte zich in de lengte uit en omwond zijne takken, (doch) hij werd gebroken en uitgerukt en uitgetrokken door hem; de boschduivel, die er inzat, verbleekte en verschrikte (69).

Hij zwaaide een stuk hout omhoog, vreeselijk van voorkomen, evenals de $n \bar{a} g a$-vorst Takșaka. De takken van zijne wortels waren (als) zijn tong en zijne verticale zware wortels waren als zijn breede bek (70).

$\mathrm{Zijn}$ harde huid, gekneusd en gebroken, was te beschouwen als zijne schubben, uitermate hard en sterk. Het van de aarde van zijne wortels opdwarrelende stof, dat was als zijn vergiftige adem (71).

Onmiddellijk daarop viel de apenvorst hem aan en stiet den rākșasa Kumbhakarṇna, niet verschillend van den zeer gruwelijken Garuḍa, die een nāga neersmakt op den bergvorst (72).

Met Indra zou men den apenvorst kunnen vergelijken; zoo was de boom, waarmede hij hem trof, als de bajra. Kumbhakarṇna was

1) Deze vertaling van alapanta steunt op eene plaats, geciteerd in Van der Tuuk's Kawi-Bal. Wdb. I, 290, s.v. alap, waar het wordt weergegeven door kalantaha (lees: Kālāntaka). 
onwankelbaar als de Meru, standvastig, stevig, onbewegelijk en onverlet (73).

Doch hij was ongedeerd, toen hij getroffen werd en onwrikbaar. Sugriwa stiet hem snel wederom met een boom, buitengewoon voortreffelijk en volmaakt van hardheid, doch hij drong niet door, maar brak, stompte af en werd afgeweerd (74).

De apenvorst werd hoe langer hoe vertoornder en kwaadaardiger. $\mathrm{Zijne}$ oogen rolden en waren rond en zijne wenkbrauwen fronsten zich. Hij gromde, gruwelijk, sperde zijn bek open en ging op één been staan en zijne slagtanden flikkerden en bliksemden voortdurend (75).

Zijn lange en groote staart trilde. De boomen, die hij naderde, vielen..$\left.{ }^{1}\right)$. Door hem gegrepen vielen zij en velen werden afgeknot. Rechts en links stieten zijne handen afwisselend (76).

Doch hij, die gestooten werd, was onwankelbaar en weerde hem af, hoe langer hoe glanzender, zeer vreeselijk en zeer gruwelijk, evenals vuur, dat hoog en hevig vlamt. Alles wat tot hem kwam werd vernietigd, zonder overschot en verdelgd (77).

Omdat hij zwak werd, raakte hij in verwarring, toen hij gestooten en geworpen werd. Rustig wierp hij een scherpe lans. Zijn stok was zeer ingelegd met goud en zoo hard als duizend, tienduizend, honderdduizende stuks ijzer (78).

Zijne tanden waren vreeswekkend en hard als echte ${ }^{2}$ ) diamant, helder glanzend, toen hij ze ronddraaide. Zijne slagtanden waren als die van god Kāla, toen hij zich vermaakte met te dansen en met opengesperden bek de wereld te verslinden (79).

Hoe langer hoe verbazender straalde de werpspies, die hij draaide. De glans van zijn pantser was helder, voortdurend verlicht en als de Meru was zijn glans, als die verlicht wordt door de twaalfhonderd zonnen bij het einde van een wereldtijdperk (80).

Hij trad ontstuimig vooruit en woest wierp hij'een werpspies; de zijde van den apenvorst was het, waarop hij mikte. Bijna had de werpspies den dapperen apenvorst bereikt; toen was Hanūmān of zijne hoede en vloog op hem toe (81).

Hij greep de werpspies zeer snel, die ruischte; ten gevolge van

1) Kahamběng wordt in Sarga VI, 138 door Prof. Kern vertaald met „afgesloten”. Ambĕng beteekent „belemmerd”. In het Nieuw-Jav. is ambĕng ,omringd". Al deze beteekenissen passen hier niet.

$\left.{ }^{2}\right)$ De vertaling van tan maya door ,echt" is in overeenstemming met Aichele in Zeitschr. f. Eingeborenen-Sprachen, Band XXI, p. 250. 
zijne grootte werd hij op den schoot genomen en opgenomen. Hij ging de lucht in, terwijl hij hem boog en hem midden doorbrak met zijn knie (82).

Alle apen juichten en verbaasd schreeuwden zij. „Ach!” zeideri zij, ,wat is Māruti dapper in den strijd!" En het daverdie in het luchtruim, dat gevuld was met voortreffelijke siddha's, die hem luidkeels toejuichten (83).

God Indra was bij het zien daarvan zeer voldaan. Allen prezen hem, zeggende: „Bravo! Bewonderingswaardig!” Want vroeger was hij overwonnen en languit uitgestrekt, getroffen door een werpspies; daarom was hij verheugd in zijn hart (84).

Het gejuich van de geheele wereld was luid. De heldhaftige rākșasa Kumbhakarṇṇa was beschaamd en uitgejouwd wordende, was hij verbitterd en vertoornd, zoodat hij een grooten berg afbrak (85).

Snel wierp hij dien op den apenvorst; hij werd verpletterd en bezwijmd viel hij achterover. Hij wist niet, dat men met hem wegliep en dat hij opgenomen werd door den voortreffelijken rākssasa-vorst Kumbhakarṇna (86).

Toen zij zagen, dat Sugrīwa opgenomen werd, vluchtten de apen en raakten zij allen in opschudding. Hunne handelwijze was mismoedig, bekommerd en vernederd, omdat hun heer geheel overwonnen was. Het hart van Marut's zoon was onverschrokken, terwij1 hij Kumbhakarṇna vervolgde, die terugweek. Hij geleek op Rudra's flikkerend vuur; zijn geest was vreeselijk, geducht en kwaadaardig (87).

Sugrīwa ontwaakte intusschen en snel kwam hij bij en kwam hij tot bewustzijn. Hij deed alsof hij een oogenblik geslapen had en helder van bewustzijn sprong hij op. Niet te vergeefs vloog hij op en beet in den vervaarlijken neus van Kumbhakarṇna. Hij greep zijn oor met zijn hand; scherp, hard, puntig en wreed waren zijne nagels (88).

De apenvorst ging weg, zijn neus medevoerende. Kumbhakarṇṇa was beschaamd, dat hij verminkt was, zonder neus en zonder oorschelp was hij als versuft en krankzinnig van toorn, beschaamd om te vluchten, verminkt, slagende. „Het is beter, dat ik sterf”, zeide hij, woedend strijdende. Onmiddellijk daarop begon hij weder de apen te verslinden, wier bloed ten einde was (89). 


\section{S a rga XXIII.}

„Blijkbaar zal een einde gemaakt worden aan het apenleger, als men hem laat begaan, den rākṣasa Kumbhakarṇna, wiens muil als die van Waḍawāmuka is. Dit is de reden, dat hij moet gedood en afgemaakt worden door den vorst". Zoo sprak Wibhịṣaṇa vermanend, deernis koesterende jegens de aarde (1).

Raghu's telg en Lakṣmana stonden oogenblikkelijk op, tegelijk een pijl aanleggende. Lakșmaṇa was de eerste, die een voortreffelijken glanzenden pijl afschoot. Zijn pantser werd vernield en zijn gouden kroon verbrijzeld, door een pijl getroffen. Hoe langer hoe woedender streed de reus, vooruittredende, niet bevreesd om te sneuvelen (2).

Raghu's voortreffelijke telg was gerust, ziende dat hij niet langer gepantserd was. Zijn pijl Amogha, zijn van ouds vertrouwd wapen schoot hij af. Deze had Kara, Triçara en Dūṣaṇa gedood in het woud. Dit was zijn schietwapen tegen hem, terwijl hij telkens gebeten werd (3).

Het dikke gedeelte van zijne beide kuiten werd doorschoten, zoodat zij braken. Zijne knieën waren het, waarmede hij liep; ten slotte liep hij met een plompend geluid, terwijl hij zijn geweldige knots zwaaide, welks ijzer schitterde, een vadem zwaar. Juist was hij voornemens, er mede te slaan, toen hij geschoten werd in zijn oksel (4).

Hij werd getroffen in zijne rechterzijde, doch de linkerzijde was er nog. Hij greep een groot stuk hout, dat hij als knots gebruikte, (doch) tevergeefs, (want) hij werd verschalkt en wederom in zijn linkerkant beschoten. Zonder handen was van zijn lichaam inderdaad alleen zijn hoofd over (5).

Gedrukt omdat hij verminkt was, werd hij hoe langer hoe vertoornder. Hij look zijne oogen niet, (maar) zij schitterden als stralend vuur. Zijne gruwelijke, scherpe slagtanden flikkerden, toen zij afgehouwen werden en hij schaterde als een bhüta, kubhända of pütana, vervaarlijk (6).

Toen zijn muil opengesperd was, werd hij geschoten en werd zijn mond gevuld. Zijn mond was vol, (zoodat) hij niet kon praten, doch bedekt was. Toen hij weder beschoten werd, werd hij afgemaakt, (doordat) telkens gemikt werd op den rākșasa. Hij miste niet, doch plantte zich in zijn hart, dat getroffen werd (7).

De pijl stak daar in zijn borst en het bloed vloeide in zijn mond en stroomde er uit. Uit zijne oogen en uit zijn mond gudste zijn bloed trillend en er was ook bloed, dat uit zijne ooren opborrelde. Toen 
viel hij op den grond, sidderend, als een bergtop, die door den bliksem getroffen is. De apen werden geklemd en platgedrukt als een rijsthoop, bedekt, dicht opeen en duizenden kwamen om, omdat hij op hen viel (8).

De godenschaar in het luchtruim juichte en schreeuwde, Hari, Hara, Yama, Baruna, Dhanada en Nirṛti. De rṣi's prezen hem, verheugd en voldaan bij het zien van het sneuvelen van hem, die opschudding veroorzaakte. De Aardgodin beefde en was eveneens verheugd en de zee was uitermate verblijd, alsof zij danste. Hare golven dartelden en speelden, bekoorlijk golvende als de hand van een verheugden pretmaker (9).

Vervolgens nadat de vermaarde Kumbhakarna gedood was door Raghu's telg, weende Daçamuka, hevig van streek en bevreesd. Toen stonden zijne zonen op, die Indrajit volgden, en hervatten den strijd. Triçirah was de oudste; daarop volgde Narāntaka en dan was er nog Trikāya (10).

Dewatāntaka was de vierde van hen; zij waren allen groote helden en jong. $\mathrm{Zij}$ hadden twee voogden, rākșasa's die hen bewaakten in den strijd, standhoudend op het slagveld. $\mathrm{Zij}$ waren bekend onder den naam Mattaka, omdat zij uitgelaten waren in den strijd en tegelijk schreeuwden. $\mathrm{Zij}$ waren dronken en verzadigd in den strijd en vroeger hadden zij alle vijanden overwonnen (11).

$\mathrm{Bij}$ het vooruittreden van Daçānana's zonen werd het apenleger verdelgd en verdrongen. Tegemoet getreden door de vorsten, vielen zij overstelpt, omdat zij vermoeid waren. Anggada stond op en hield een voortreffelijke knots in de hand, terwijl zijn hart kookte. Narāntaka werd door hem aangevallen, met de vuist geslagen, vernietigd en afgemaakt (12).

Triçirah en de sterke Trikāya trachtten den strijd te hervatten, vertoornd en driftig; met hun jongeren broeder Dewatāntaka kwamen zij hem tegelijk overvallen. Zij trachtten Anggada te omsingelen, doch hij ontsnapte, bedreven, dapper en handig. Hij verstond de kunst van zich te verwijderen en vloog weg; hevig geslagen wordende, look hij zijne oogen niet (13).

De aap Nìla en Anggada's zoon hielpen snel Anggada, vooruittredende. Een bergtop werd omhooggehouden als een van ouds beproefd, onfeilbaar wapen. Triçirah schoot eene onafgebroken menigte voortreffelijke pijlen af. $\mathrm{Zij}$ werden geknakt, afgestompt en verpletterd, als zij den harden berg ontmoetten (14).

De ijzeren knots van Dewatāntaka schitterde, toen hij er wreed 
mede sloeg. Hij beukte zijne dijen en ribben; zijn hals werd snel getroffen zonder dat hij het voelde. Pawana's zoon was in verlegenheid, omdat hij getrokken en gekweld werd door hem. Met de knokkels geslagen, werd hij ten slotte afgemaakt; met de vuist geslagen, wenschte hij niet te sterven, gemarteld wordende (15).

Ook zijn voogd Matta sneuvelde door de hand van Çarabha, krachteloos, door een knots getroffen. En Samaramatta werd door Nila fijngewreven met een grooten berg. Triçirah streefde voortdurend naar roem, zijn krtāla die schitterde zwaaiende. Hij werd overwonnen door Anila's zoon, die hem hieuw met zijn zwaard en hem ten val bracht (16).

De krachtige Atikāya bleef achter, vooraan; zijn strijd duurde lang. Duizend paarden trokken zijn wagen, als bergen, zoo wonderbaarlijk groot. De apen kermden, fijngemalen en platgedrukt door de raderen van den wagen, die hen snel vervolgde. Sommigen werden vertrapt of gebeten door de paarden, die trappelden en zich in het stof wentelden, trachtende te trekken (17).

De jonge Lakșmaṇa had medelijden met de apen, die gekweld en woedend aangevallen werden en vergolden werden. Hij trad op den krachtigen Atikāya toe, beiden even sterk in het boogschieten. Hunne pijlen suisden en zij raakten elkaar aan en troffen samen. Schitterend boden zij tegenstand in het luchtruim; geen van hen deerde, al brandend (18).

Daar was de Saura en Mahendra's schicht, de Içika en Pāwaka's pijl. Dat waren hunne pijlen en hunne schiettuigen ontmoetten elkaar zonder dat er een was, die verwondde. Toen herinnerde de jeugdige Lakṣmaṇa zich Brahmā's pijl Çūrawijaya. Deze doodde Atîkāya, die niet werkelijk sterk was, omdat hij sneuvelde (19).

$\mathrm{Na}$ den dood van zijne zonen, die opgetrokken waren en toen ook hun voogd overwonnen was, besefte ook Daçānana, dat hij overwonnen was en dat zijn dood zeker was. Onverschillig over de overwinning, was zijn hart afgestompt en wenschte niets anders dan te sterven. Er was geen ander kind van hem meer; alleen Indrajit bleef over als laatste (20).

„Laat mijn einde zijn, vader, dat ik sterf, indien de vijand overwint. Ik zou in staat zijn, om duizend Rāma's te weerstaan. Hij zal door mij vernietigd, verdelgd en afgemaakt worden. Nadat hij afgemaakt is, zal ik gaan, om de apen, zijne stamvrienden te verslaan. Hei! Door mij aangeraakt, zou hij verdelgd worden, al ware hij een berg, laat staan een onrein mensch (21). 
Als vermagerde herten en hazen zijn zij in de bosschen, doende alsof zij ascese verrichten, doch hunne ascese is niet echt; slecht, schandelijk en krenkend leggen zij de gelofte van den reiger af; wiku's als een verrot ei, van buiten wit, (doch) van binnen slijmerig en stinkend. Daarmede is Rāma te vergelijken, die geloften overweegt, (doch) steeds doodt, weshalve hij gedood moet worden" (22).

Zoo sprak ${ }^{1}$ ) Indrajit, een leeuwengebrul aanheffende en zeer dapper en fel stond hij op. Zijn vader was niet langer bedroefd, ziende hoe gruwelijk hij was, als een leeuw. Snel ging hij op weg, uittrekkende naar het slagveld, na geofferd te hebben en na als gunstbewijs een grooten wagen ontvangen te hebben en een verbijsterenden pijl, een geschenk van de godheid aan hem (23).

Toen hij ten strijde trok, ging god Rawi onder en werd het duister en somber. De tien hemelstreken werden alle donker. Indrajit prees overmoedig. Hij zag, terwijl er niemand was, die hem zag. Hij wendde de tooverkracht aan van het onzichtbaar makende tooverformulier. $\mathrm{Hij}$ beschoot de apen met den verbijsterenden pijl, (waardoor) zij sliepen en in slaap vielen (24).

Toen het apenleger rustig sliep, lachte Indrajit zeer luid. Hij was niet ongerust, om de snurkenden te dooden; verraderlijk was zijne handelwijze en tegen alle recht. Honderden, tienduizenden, honderdduizenden apen stierven door zijne hand, daar hij hen onophoudelijk beschoot. Ver van hem verwijderd was Raghu's voortreffelijke telg; er was geen aap meer levend (25).

De voornaamste en vermaarde apen waren dicht bij Raghu's telg. Zij waren nog wel levend, maar hunne oogen waren slaperig onder den invloed van het slaapformulier. Zelfs de voortreffelijke telg van Raghu werd niet gespaard door den verblindenden pijl. Vakerig en slaap hebbende praatte hij in zijn slaap, terwijl hij nederlag met zijn jongeren broeder (26).

Nadat de vorst getroffen was door den verblindenden pijl, vluchtte hij, die zich onzichtbaar gemaakt had, terug uit vrees, dat hij bemerkt zou worden door zijn vader (oom) Wibhịsana en dat deze hem zou vergelden. Hij was niet onder den invloed gekomen van het slaapformulier, niet vermoeid, met over de borst gekruiste armen, zijne oogen wrijvende. Zijne oogen waren voortdurend stralend en hij was klaar wakker, op zijne hoede, beleidvol en bekwaam (27).

Het tooverformulier, Dīpasañjata genaamd, dat overwon het slaap-

1) Voor huwus, zooals in den tekst staat, leze men: wuivus. 
formulier. Dat was in hem, waardoor hij niet onder den invloed was gekomen van den verbijsterenden pijl. Hij zweeg voortdurend, zijne aandacht richtende op de tooverspreuk en trachtende te bidden $\mathrm{Hij}$ duchtte, dat de groote reus Indrajit zou komen, want hij was een held in den strijd (28).

Hij werd onmiddellijk ongerust en stak toortsen aan; toen werd de vorst zichtbaar in de gedaante van iemand, die bezeten was door een pişāca met schuimenden mond en glurende oogen, zuchtend en tevens verbijsterd van zin, als de geest van een benevelden. Hij werd gewekt en gelast, zich te reinigen; het was alsof hij weer tot bezinning kwam en ophield te slapen (29).

Ook de apenvorst werd wakker geschud en Marut's zoon, Nila en Anggada werden gewekt. $Z \mathrm{ij}$ staarden, luid sprekende; verrast bij het zien van de toortsen, grijnsden zij. De toortsen van Wibhị̦aṇa vermenigvuldigden zich en men zag de lijken opgestapeld. Alle apen waren vee, na gedood te zijn in den verraderlijken strijd (30).

Raghu's voortreffelijke telg had zeer hevig medelijden bij het zien van de neergezegenen. Hunne wijze van sterven was niet die van helden, doch ongemerkt gedood stierven zij rustig. Daarop werd Marut's zoon gelast, het uit amrta bestaande wonderkruid te halen, (opdat) de lijken weder zouden herleven door de tooverkracht van de genezende slingerplant (31).

De plaats, waar het voortreffelijke wonderkruid zich bevond, was de top van den Himagiri. De plaats, waar de genezende slingerplant groeide, was bekend als Wiçalyakarinīi, de dooden opwekkende en de gewonden genezende; dat werd hij gelast, om op te sporen. Zonder te weerstreven ging Marut's zoon, vliegende naar den Himagiri (32).

Hij was echter niet bekend met het wonderkruid en hij stond ontsteld en verlegen. Ten slotte knotte hij den berg af en vloog er mede weg. In een oogenblik kwam hij; met de wortels werd het kostbare wonderkruid medegevoerd en het vertoonde zich in menigte. Het werd genomen door den vorst als een middel, om alle dooden daarmede te besprenkelen (33).

$\mathrm{Na}$ het sprenkelen met het kruid over de overledenen ontwaakten

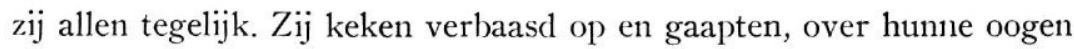
strijkende, alsof zij geslapen hadden, knikkebollende. Zij likten aan den $a m r t a$, een weinig, werden opgewekt en hieven allen een leeuwengebrul aan. Hun gemoed was ongeduldig, om terug te keeren naar het slagveld en zij hadden allen stokken in de hand (34).

Wegens de wreveligheid van het apenleger, dat zij gedood waren 
en geslapen hadden, verbrandden zij de stad van Rāwạ̣a, die vlamde en zonder overschot tot asch werd. Het leger van Daçānana was verwonderd en verbaasd, ziende dat de residentie in brand stond. Indrajit verbleekte; omdat hij zoo snel vergolden werd, werd hij bleek, dat ziende (35).

Toen trokken twee broeders uit, Kumbha en Nikumbha, den strijd hervattende. Als een koperen pot waren hunne oogen, verschrikkelijk rood, breed en rond. Immers Kumbhakarṇna had hen tot zoon; buitengewoon groot was hun lichaam, als een berg. In alle listen van het slagveld was er van oudsher niemand, die hen kon weerstaan (36).

Er waren voortreffelijke rākșasa's, Kampana en Akampana genaamd, ervaren, en Prajanggha, Wimohitāçwa, de vermaarde en ook Dhwajākșa. Zij beschermden Nikumbha en Kumbha, verlangend dat alle apen zouden onderdoen, want zij hadden vroeger overwonnen in den strijd en hun streven was, om woedend te strijden en te overwinnen (37).

Bij het woedend strijden van die zeven tegelijk, wenschten zij te sneuvelen, rücksichtslos en standhoudend. Hun aandringen was vurig als het doodsvuur, het apenleger verbrandende en verdelgende. Iedere held van het apenleger, die hen naderde, werd weggeduwd en de goede bewakers werden teruggedreven. $\mathrm{Zij}$ werden mede ongerust en kwamen in beweging, gescheiden als de zee, die ebt en ophoudt, vol te zijn (38).

Prins Rāma beval snel, om hen, die achtervolgden, te verslaan. Er was geen ander dan Anggada, die standvastig was in het afweren en altijd tegenstand bood, vast in zijn trouw, trouw jegens Raghu's voortreffelijken telg en grenzenloos liefderijk. Hij gaf niet om den dood van zijn vader, omdat deze oneerlijk en onrein van gedrag was (39).

Ook was hem de heerschappij van een kroonprins geschonken en verdiende hij zich te vermaken als een vorst. Dat was de reden, dat hij verlangde naar het slagveld als een minnaar, die de liefde kent. Steeds bewaarde hij de verplichting in zijn hart, voorgesteld als een groote tempel. Raghu's voortreffelijke telg was het, in het binnenste gevestigde, voortdurend vereerde juweel (40).

Hecht was de toewijding van Anggada, terwijl hij Akampana, dat rund, afmaakte. Toen werd wederom Kampana gegrepen en op een harde steenplaat neergesmakt. Vervolgens werd Prajanggha door hem met een mes in zijne linkerzijde gestoken, zoodat hij zich verslikte. Hij sloeg op zijn gelaat; zijn neus werd 
ingedrukt en zijne oogen werden platgedrukt, zoodat zij er uitspatten (41).

Toen greep hij de banier van Dhwajākșa en deze viel, getroffen door zijn banier. Hij drukte met zijne knieën op het midden van zijn rug en zijn hals werd omgedraaid en gebroken. De krachtige en stevige Dwiwidha, wiens borst niet ruig was, zwaaide zijn knots afwerend omhoog. Wilohitākṣa, op Takṣaka gelijkende in felheid, streed woedend, doch werd verbrijzeld, geslagen wordende (42).

De aap Mainda draaide zijn knots rond en streed strijdlustig mede. Hij werd in het nauw gebracht, doordat hij beschoten werd door Kumbha; bijna sneuvelde hij, getroffen door een speer. Hij was zeer zwak op het slagveld; steeds werd hij in het nauw gebracht. Plotseling trad hij vooruit, zijn knots zwaaiende; hij was immers sterk, al leed hij pijn (43).

Anggada was bezwaard, ziende dat zijn oom Mainda hulpeloos was. Een bergtop hield hij in de hoogte, alsof hij met een bal speelde, onvermoeid. Anggada mikte op het gelaat van Kumbha, terwijl hij hem wierp. Zeker zou hij gesneuveld zijn, verpletterd onder den berg, als hij niet had weten te vergelden (44).

Doch hij kende het wapen, Pratipa genaamd, een afwerenden pijl. De berg werd teruggekaatst en teruggeworpen, doch Anggada was sterk in het vergelden. Zijne hand werd vermoeid door het onophoudelijke terugwerpen van zijn werptuig. De berg keerde voortdurend terug, alsof hij rondwandelde en zich verlustigde (45).

De apenvorst was beschaamd, ziende dat zijn stiefzoon, Bāli's zoon, teruggedreven werd. Immers zou hij Kumbha in eens afgemaakt hebben met zijn vuist. Zijn oudere broeder Nikumbha hervatte den strijd, geducht, een strijdhamer dragende. Pawana's zoon was verbaasd; als een adelaar greep hij zijn knots, doch die werd geknakt (46).

Als een leeuw beet hij in den hals van Anikumbha, die gelijk een olifant was. O! Zeer meedoogenloos werd hij gedood'door Samirana's zoon! Bij den dood van de beide broeders waren hunne dienaren bedroefd, (doch) zij werden meegesleept en sneuvelden. Hunne snoode en booze aanvoerders werden mede luidruchtig achtervolgd, doch sneuvelden niet mede (47).

Daçamuka werd alleen gelaten; deerniswaardig bleef hij alleen achter. Waarschijnlijk zou de dood eindelijk tot hem komen. Bij den dood van de getrouwe helden begon hij na te denken. De bezetenheid van zijn gemoed verzwakte en weenende kwam hij tot bezinning (48). „Ach! Wat is het doel van de vreugde?” dacht hij. „Wat is het 
nut van macht en verwaandheid? Het is smakeloos, als men het proeft. Inderdaad zijn de overheerschende zinnelijke genietingen ten slotte vergif. De dood is de grens van het leven. Wie ontkomt daaraan?" (49).

Zoo en vervolgens waren de treurige woorden, in zijn hart geïmproviseerd. Voor het eerst werd hij getroffen door leed en verminderde zijne gewelddadigheid en werd hij bedroefd. Daarop maande zijn zoon hem aan, onvervaard te zijn in zijn gemoed en dat hij zijn mannenmoed op het slagveld zou toonen (50).

$\mathrm{Na}$ zijn gemoed opgebeurd te hebben, sprak Indrajit een tooverspreuk uit, zwijgend. Hij was niet bevreesd te sterven, maar luidruchtig streefde hij naar heldhaftigheid. Hij trok uit, den strijd hervattende, opdat de vijand zou vernietigd worden en ineens verdelgd worden. Verslagen te worden en te overwinnen, af wisselend, heen en weer, zoo handelde hij (51).

Bij het uittrekken van den geeërden en beroemden Indrajit met zijn leger vergezelden hem zijne voortreffelijke vrouwen, waarvan hij niet gescheiden was; vrouwen van hemelsche schoonheid waren zijne echtgenooten, onvergelijkelijk, dochters van Apsarasen, zeer goddelijk en navolgenswaardig (52).

Zeven waren zij, allen zusters, trouw van hart en standvastig. Haar gemoed was doordrongen van den dood; zij waren trouw en niet aarzelend, inderdaad van edele geboorte en zuiver van inborst. $\mathrm{Zu}$ zouden terugkeeren naar Indra's wereld en weder gelukkige Apsarasen worden (53).

Allen waren zeer dapper en heldhaftig, het leger, dat wederom vooruittrok. De olifanten, wagens en wagenmenners waren standvastig in hunne slagorde, ervaren en bedreven. Voortdurend waren zij nauwgezet; om te eten op het slagveld, was steeds hun doel. Hun lichaam was van litteekens voorzien, hun baard was donker en hunne voeten scharrelden $(54)$.

In den strijd van het leger geleken zij op eene versperring, waren zij ingesloten en draaiden zij rond. Zij beukten op het achterste deel van den rug en vormden de achterhoede. Het apenleger was onverschrokken; toegeschreeuwd en bedreigd wordende, streden zij woedend. Zij werden overweldigd, overstelpt en door slingers getroffen, doch zij sloegen terug en staken (55).

Een troep was met schilden gewapend en kwam, al stekende, want zij waren bedreven, doch zij werden in de pan gehakt. Hunne sieraden waren met goud getooid en zij straalden en flikkerden hier 
en daar. Het geheele apenleger was verblind bij het zien van die pracht, alsof zij inderdaad niet zouden onderdoen, als zij tegelijk staken en aandrongen (56).

En de met lansen gewapenden stelden zich tegenover hen en verhoogden de schoonheid, hen vergezellende. Vervaarlijk waren de stokken van hen, die met schilden gewapend waren, nabij. De apen waren strijdlustig en woest, getroffen door gulum's ${ }^{1}$ ) en lansen. Juist waren zij neergezegen, meegesleurd door de met schilden gewapenden, omdat zij woest waren (57).

De met schilden gewapenden waren zeer overmoedig, verlangende te wonden en te snijden. $\mathrm{Zij}$ werden gesteenigd met vlakke steenen en geknakt; bij het gebogen worden, zegen zij neder. Bij het heen en weer bewegen der zich onrustig bewegenden werden de houten, waarmede zij sloegen, gebroken. Sommigen werden bedolven onder bergen en werden tot $t_{p a y}{ }^{2}$ ) (eene lekkernij), die zich verspreidt (58).

Allen die met knotsen gewapend waren stelden zich op en brachten hen, die met schilden gewapend waren, in het nauw, omdat zij vermoeid waren; zij die met lori's gewapend waren beukten voortdurend en sloegen aanhoudend. Zij die met krtala's gewapend waren werden luid toegeschreeuwd, zoodat de apen ontsteld werden. Verward wierpen zij met werpschijven; in volgorde kletterden de met werpschijven gewapenden, al treffende (59).

Rustig en onbewegelijk hield het leger van Indrajit stand, daar hij standvastig was. Hij was ongeduldig, dat de vijand verslagen en verdelgd zou worden en hij trad vooruit. Prins Lakșmana was zijn tegenstander, strevende naar roem. Beiden waren zij bedreven in de wapenen, ervaren in het boogschieten, warm en koud (60).

Het eerst schoot prins Lakșmaṇa pijlen af. Hij had als schiettuig den, uit water bestaanden Baruṇāstra. De tooverkracht ervan was, dat het veld geen middel daartegen had, dat het veranderde in een zee. Het leger van Indrajit verzonk daarin en krachteloos verdronken zij allen (61).

De vuurpijl, waarmede hij afweerde, schitterde, straalde en likte voortdurend. Deze nu verdelgde het water, zoodat het opraakte en vluchtte, verschroeid en afdwalend. Nadat het water op was, keerde het vuur terug. Bij de afwezigheid van boomen kon het niet standhouden en keerde terug (62).

1) Gulum is de naam van een wapen, doch het is niet bekend van welk.

2) In plaats van ta paya garawayan leze men in de editie: tapay agarawayan. 
Wederom schoot Indrajit en verscheidene (pijlen) kwamen er uit, al dwarrelend. De befaamde Asurāstra deed zwaarden en knotsen te voorschijn komen, bijlen, knotsen, drietanden, dicht opeen, vergezeld van vuur. De werptuigen verdwenen, vermengd met steenen en stof, dat warrelde en fonkte (63).

Wat was het middel, om dien te overwinnen? De Maheçwara-pij] was een beschermmiddel, een pijl, die alles verslond wat tot wapen diende en afgeschoten werd. Dit was het schietwerktuig van den jongeling Lakșmaṇa, waarmede hij overwon. Alle wapens van Indrajit verdwenen, werden gebroken en vlogen weg (64).

Hij werd mishandeld, daar hij vermoeid werd en onthutst, omdat hij voortdurend beschoten werd. „Ik word flauw” dacht hij, die vroeger gewelddadig ${ }^{1}$ ) en sterk was. Op den olifant, den wagen en den wagenmenner van Indrajit werd gemikt. $\mathrm{Zij}$ werden allen verdelgd en vernietigd, zonder overschot. Hij alleen werd gemist (65).

Alleen bleven verscheidene banden over, die alle trachtten vooruit te gaan. Hij had geen wagen en geen wagenmenner meer, toch trachtte hij slechts woedend te strijden. Daarop werd hij beschoten met een Indra-pij1 en een Rudra-pijl. Deze brak den hals van Daçawadana's zoon (66).

Ook zijne zeven gemalinnen stierven allen. De gelofte van huwelijkstrouw werd zoo door haar vervuld. De wijzen prezen hem, verheugd bij het zien van zijn dood. Blanketsel en een bloemregen vielen voortdurend, zich verspreidend (67).

Bij den dood van Indrajit klonk het luid ,heil! heil!” in het luchtruim. $Z_{\mathrm{ij}}$ prezen den edelen Lakṣmaṇa, die in staat was, den hinderpaal uit den weg te ruimen. Het hart der goden was verheugd, verlangend te prijzen, zeer druk en blijde. Zij strooiden geurige en welriekende reukwerken uit het luchtruim (68).

Daçawadana was zeer treurig, omdat zijne toevlucht ten einde was. $\mathrm{Na}$ den dood van zijne zonen en zijn leger was hij evenals een boom, die onttakt is. Wel was zijn romp er nog, doch het was moeielijk, om te blijven leven. Zeker zou hij vallen, omgehakt door den eigenaar van den boom (69).

Het was niet te vermijden, dat hij ten strijde zou trekken en met vrucht woedend zou strijden. Zeker en stellig was ten slotte zijn dood en dat hij in den strijd zou sneuvelen. Ten slotte hield hij op,

1) Balikari ontbreekt in de Oudjav. woordenboeken.

D1. 92. 
treurig te zijn, kwam hij tot bewustzijn en was zijn gemoed onovertrefbaar. Wederom was hij opgewekt en niet bevreesd, dat hij zou sterven, (doch) zeer verheugd (70).

Hij trad den Çiwatempel binnen, waar de goden aangeroepen worden, om te offeren. De geweldige en verschrikkelijke Paramaguru werd door hem aangeroepen. Hij ging uit, om zijne opwachting te maken in het gebouw, waar de vootreffelijke Brahmanen gereed stonden. Hij stond op, onheil afwerend en geluk voorspellend was het beloop van zijn verhaal (71).

Blaasinstrumenten, schelptrompetten en glasinstrumenten weerklonken daar, vreugde veroorzakende. Feestmuziektrommels accompagneerden hen, alsof het een geschenk was van hen, die tegelijk speelden. Daçāsya was verheugd in zijn hart, omdat de Brahmanen ,zege! zege!” riepen. Hij strooide geschenken uit, zeer eerbiedig jegens hen allen (72).

Het leger wachtte langzaam op het uittrekken van vorst Daçawadana. De werktuigen voor het slagveld waren gereed gezet. Hij trok zijne oorlogskleeding aan, zijn helm was van goud en juweelen. Zijn glans schitterde rood, zuiver als zijn hart (73).

Daarop besteeg hij een grooten, met goud versierden wagen, als de top van den berg Sumeru, van goud gemaakt. Zijne paarden waren als paarlen en smaragden, om te zien, en hun lichaam was groen. Toen stond hij op zijn wagen, gelijk de zon (74).

Zijn leger was zwaar, glanzend, allen in gouden pantsers gehuld. Zij omgaven en zij volgden hem, hangende dicht bij zijn wagen. De haren van hunne schilden waren roode cāmara's met losse tanden, evenals een wolk, wanneer zij pas getroffen is door den glans van god Aruna (75).

Hunne gouden pantsers glansden en begonnen te flikkeren. Hunne slaginstrumenten bulderden luidruchtig tot in het luchtruim. De banieren waren als een regenboog; de wimpels zagen er uit als een regenboog. Als een vergiftige regen waren hunne scherpe en heete pijlen (76).

Zij kwamen voorovervallende, met open mond, klagende en krijschende. Ook het leger van Raghu's voortreffelijken telg trad vooruit, al dansende. Beiden waren even grimmig bij hunne ontmoeting en beiden beukten heldhaftig. Het was alsof de grond zou scheuren, door hen betreden, die onafgebroken stormden (77).

Het stof dwarrelde, zoodat het slagveld donker en duister werd. 
Men kon zijne tegenstanders niet zien, maar was dooreengemengd, verward en vermengd. Overal traden de patih's vooruit, terwijl zij allen zonder onderscheid vervolgden. Ieder, dien zij tegenkwamen, was beklagenswaardig; zij trokken hun dolk en trokken dien uit (78).

„Ik ben een aap”, spraken de apen tot hunne makkers in het apenleger. „Ik ben N.N., een rākșasa; mijn streven is, om te beschermen”, zeiden anderen. „Ach! Wat toch? Ieder, die gegrepen wordt en onachtzaam is, sterft. Ik wensch niet te leven. De dood is het lot van de geheele wereld" (79).

Zij snaterden en kermden; sommigen hadden een open mond, weerden af en stieten omver. Er waren andere räkșasa's, wier hals omwonden werd met hun staart. Hun kaak werd gestooten; de slagtanden van velen, die beten, werden gegrepen. $\mathrm{Zij}$ werden meegesleept en geknepen en hun hoofd werd geklemd, getroffen door een hamer (80).

Allen, die gewond waren, sneuvelden; hun bloed stroomde gruwelijk. Dit nu wischte het stof weg, dat ophield te dwarrelen; de duisternis verdween en het werd helder. De reuzen straalden; de rākșasa's, waarop gemikt werd, sneuvelden bij duizenden en werden verdelgd, beschoten door Raghu's telg (81).

Daçānana was op zijne hoede, ziende dat zijn leger bevig bestookt werd. $\mathrm{Zijn}$ wagen knarste snel en hij ging vooruit, doch werd teruggedreven; als een voorteeken, dat hij ten slotte zou overwonnen worden in den strijd, stak er een storm op, vergezeld van kraaien cn duisternis (82).

Doch de reuzenkoning Daçāsya schrikte niet en was niet mismoedig, maar hij streed woedend. Hij beval zijn leger zich in te spannen. Daarop trad hij, die Wirūpākṣa heette, naar voren. Hij was op een olifant gezeten en droeg een scherpe, geduchte werpspies, die hij draaide. Sugrīwa trad hem tegemoet in den strijd en hij sneuvelde in eens, krachteloos, toen hij geslagen werd (83).

Dhūmrākșa trad verbitterd naar voren, trachtende den strijd te hervatten. Sugriwa doodde hem door hem te werpen met een steen, zoodat hij ineenzakte en verpletterd werd. Mahodara juichte en trad woedend strijdend naar voren, roem willende verwerven. Hij werd met de vtiist geslagen door Anggada in den strijd en zijn hoofd werd verpletterd, gebroken en verbrijzeld (84).

$\mathrm{Na}$ den dood van de drie patih's, Wirūpākșa, Dhūmrākṣa en Mahodara, werd het hoe langer hoe duidelijker en blijkbaar en on- 
148 VERTALING VAN SARGA XXII EN XXIII OUDJAVAANSCHE RāMāYẠ̣A.

vermijdelijk, dat de dood over Daçāsya zou heerschen in den strijd. Zijne woestheid vertoonde zich volledig, toen hij onder verscheidene zwakke apen amok maakte. Volmaakt en vast was zijn heldenmoed en hij gevoelde, dat hij niet zou wijken, op Rudra gelijkende in woestheid (85). 
